\title{
Deconstructing the Gecekondu
}

Jean-François Pérouse

\section{(2) OpenEdition \\ Journals}

\section{Electronic version}

URL: https://journals.openedition.org/ejts/195

DOI: 10.4000/ejts.195

ISSN: $1773-0546$

\section{Publisher}

EJTS

\section{Electronic reference}

Jean-François Pérouse, "Deconstructing the Gecekondu ", European Journal of Turkish Studies [Online]

1 | 2004, Online since 04 March 2015, connection on 27 May 2021. URL: http:// journals.openedition.org/ejts/195 ; DOI: https://doi.org/10.4000/ejts.195 
Citation: Pérouse, Jean-François (2004) 'Deconstructing the Gecekondu', European Journal of Turkish

Studies, Thematic Issue Nº1 - Gecekondu, URL: http://www.ejts.org/document195.html

To quote a passage, use paragraph (§).

\title{
Deconstructing the Gecekondu
}

Jean-François Pérouse

\begin{abstract}
This paper is a short, English version of the introducing paper of the thematic issue, originally in French : "Les tribulations du terme gecekondu (1947-2004) : une lente perte de substance. Pour une clarification terminologique », European Journal of Turkish Studies, Thematic Issue №1 Gecekondu, URL : http://www.ejts.org/document117.html
\end{abstract}


It will soon be 50 years (according to Yerasimos, Vaner: 1988) since the word gecekondu - a prime example of the vividness of expression in Turkish ${ }^{1}$ - came into use. Yet the word is so overused that it has all but lost its relevance, conceptual accuracy and explanatory power. As Ersan Ocak puts it in a recent article (2002: 91), the word gecekondu is a 'ready-to-think' product, 'the conceptualization [of which] is insufficiently inadequate'. As an inhibiting rundown of research on contemporary Turkey, the word gecekondu, calls nothing clear to mind, and therefore cannot be used any more as such without spreading prejudice or confusion. One can even say that this word has become (from the scientific point of view) counter-productive. Taking inventory of all the scientific fields in which it is used (urbanism, architecture, sociology, anthropology, ethnology, geography or political sciences) demonstrates the crisis of misuse and misconception that the word is facing. Moreover, its various translations show all its polysemy and vacuity: translated into French by 'bidonville', in English by 'slum', 'shanty' or 'squatter's house' or 'squatter town', each of these translations is in fact an interpretation that refer to research traditions and development-oriented state interventions everywhere but in its Turkish context. And we'd better be conscious of this if we mean to build on a common language. In that respect, instead of repeating usual but always frightening figures - like for example one million gecekondu in Istanbul, representing half of all the city's constructions! - a more accurate and closer look at it seemed necessary.

[2] Scholars overuse the word gecekondu to make arguments about urban poverty, internal migration, urban land ownership, social movements, housing policies or self-construction practices; each author has his/her personal and implicit vision of the gecekondu. What is the use of giving the exact number of gecekondu in Turkey - or even the number of those being built every day - or the percentage of the urban population living in gecekondu, if one doesn't know what it's all about?

1 Other new words were developed on the model of gecekondu : apartkondu, mezarkondu, camikondu, surkondu, kent kondu, seçimkondu... 
[3] In other words, shall we ban from scientific debates this 'concept' which doesn't seem to fulfill any satisfying heuristic function? Otherwise, in which conditions shall we use it and what precautions shall we develop? How shall we reconcile it with the architectural approach (that is willingly or unwillingly fetishizing a type of construction which is in fact historically dated ${ }^{2}$ ), with the urbanistic approach (which is more interested in legal mechanics), and with the sociological or anthropological approach? The present work aims to collectively deconstruct the gecekondu, in order to possibly build it anew. In that respect, we have invited the contributors of this issue to reread the major writings on the issue (Yavuz 1953, Öğretmen 1957, Gençay 1962, Yasa 1966, Yörükhan 1968, Asma 1971, Keleş 1972, Akçay 1974, Şen 1975, Karpat 1976) so as to come together with a common language that would be more accurate and operational. In that way, we might be able to free the debate from a too systematic assimilation of gecekondu with for example peripheries, urban poverty, or with illegal housing. The definition first suggested in 1953 by Fehmi Yavuz could be referred to as a starting point of study: 'The gecekondu are hastily erected buildings, lacking most of the times elementary comfort conditions, not conforming to construction regulations and being developed regardless the land owner's rights'3.

[4] In this EJTS issue, following the sound advice of Şenyapılı (1998), we propose articles oriented on the following questions regarding gecekondu (without limiting the topic to housing problems):

[5] The first general and conceptual paper by Jean-François Pérouse traces the history of a word and its conceptual drift. In the same time, through an auto-critical approach, the author reexamines the use of the concept by research in order to identify its contradictions and ambiguities, as well as the underlying gecekondu ideologies in scientific

\footnotetext{
2 What is actually encouraging some architects to affirm that no more gecekondu are being built today.

3 Let us note that this definition is surprisingly close to the one we find in the well-known "gecekondu law" passed in 1966, which states in article 2: "In this law, the term Gecekondu refers to illicit constructions, that were built regardless the general regulations and directives determining construction work requirements, regardless the soils on which building is permitted or not, regardless the fact that land do not belong to the builder and that gecekondu are being built without the owner's authorization'.
} 
debates. This work leads to redefine the concept ${ }^{4}$ and enables to clarify what we are talking about in debates.

[6] We believed it might be interesting to look back at one of the most used scientific reference on the gecekondu phenomenon, The gecekondu : Rural Migration and Urbanization (1976), more than twenty five years after its release. Its author, Kemal $\mathrm{H}$. Karpat, details the genesis of this writing. What is its reach and impact? Can we trace back its lineage?

[7] Benoit Fliche then tries to understand the gecekondu beyond common categories like "rural" or "urban". He argues that the gecekondu, which has often been described as a "urban village" should be analysed through more relevant categories, after looking at the daily practices and discourses.

[8] The fourth article, by Tahire Erman and Naslihan Tok, reviews gecekondu studies in order to reveal the changing representations of the phenomenon in the academic field. They show that gecekondu is always built as a figure of the "Other".

[9] In his paper on the image of gecekondu through Turkish movies, Mehmet Öztürk grants attention to the Turkish film industry in order to understand how movies have contributed to the myth of gecekondu since the 1960s.

[10] Tansı Şenyapılı tries to untangle the logic behind the development of gecekondu. Could it only be a kind of land and real estate speculation? Moreover, is the systematically mentioned relation with migration towards larger cities, housing crisis and development of gecekondu always relevant? In other words, is the development of gecekondu the automatic answer to the housing crisis, that is itself a result from the migration pressure to large cities?

[11] Marie Leray then studies local politics, local memories and gecekondu in Bir Mayıs Mahallesi. Policemen's representations, passed on by the media, tend to present

\footnotetext{
${ }^{4}$ Beside the given definitions, let's mention the one by Gençay (1962: 5), which prioritizes the illegal feature of the occupancy : 'Hastily built housing, on a land that do not belong to the builder breaking construction laws and regulations, regardless sanitary and technical requirements and norms'.
} 
Citation: Pérouse, Jean-François (2004) 'Deconstructing the Gecekondu', European Journal of Turkish Studies, Thematic Issue N¹ - Gecekondu, URL: http://www.ejts.org/document195.html To quote a passage, use paragraph (§).

gecekondu like hideouts and even natural breeding grounds for illegal political organizations. From the 'liberated zones' of the 1970s to the recent case of Küçükarmutlu, it seemed interesting to give a closer look at this relation. Marie Leray's approach, based on a field study in Bir Mayıs Mahallesi, gives some insight into organized and territorialized collective mobilization processes on gecekondu scenes.

[12] Considering the gecekondu as an environment with specific features, Heidi Wedel finally examines how gecekondu districts pre-structure social space and political participation. She shows that gendered place and space in gecekondu lead to gendered political priorities and action. The article discusses the effects and constraints of women's collective actions regarding political awareness, local leaders, and formal political participation. 


\section{References}

Akçay, Faik (1974) Zeytinburnu : Gerçek Yönleriyle bir Gecekondu Kenti, Istanbul, Çelikçi Matbaası.

Asma, Tahir (1971) Rural-urban Migration : "Night Squatter" communities of Istanbul and Ankara, PhD Thesis, Milwaukee, University of Wisconsin.

Gençay, M. (1962) Gecekondu Problemi, Ankara, Imar ve İskân Bakanlığı Yayınları, Komisyon Raporları $n^{\circ} 6$.

Karpat, H. Kemal (1976) The Gecekondu. Rural Migration and Urbanization, Cambridge, Cambridge University Press.

Keleş, Ruşen (1972) 100 soruda Turkiye'de Şehirleşme, Konut ve Gecekondu, Istanbul, Gerçek yayınevi.

Ocak, Ersan (2002) 'Yoksulun evi', in Erdoğan, Necmi (der.) Yoksulluk Hâlleri. Türkiye'de Kent Yoksulluğunun Toplumsal Görünümleri, Istanbul, De:ki, pp. 89-115.

Öğretmen, Ibrahim (1957) Ankara'da 158 Gecekondu Hakkında bir Monografi, Ankara, Ajans Türk Matbaası.

Şen, Faruk (1975) Die Entwicklung der Wohngebiete der Stadt Ankara seit 1923 unter besonderer Berücksichtgung des Gecekondu Phänomens, Thèse, Université de Saarbruck.

Şenyapılı, Tansı (1998) 'Cumhuriyet'in 75. Yllı. Gecekondunun 50.Yılı', 75 yılda değişen Kent ve Mimarlık, Istanbul, Tarih Vakfi, pp. 299-316.

Vaner, Semih ; Yerasimos, Stéphane (1988) 'Petite chronique des "gecekondu", in Istanbul, Paris, Autrement, Série "Monde" H.S., n²9, pp.151-154.

Yasa, İbrahim (1966) Ankara'da Gecekondu Aileleri, Ankara, Sağlık ve Sosyal Yardım Bakanlığı, Sosyal Hizmetler Genel Müdürlügü Yayınları, nº4.

Yavuz, Fehmi (1953) 'Bina yapımı teşvik', Iller ve Belediyeler Dergisi, pp.63-68.

Yörukhan, T. (1968) Gecekondular ve Gecekondu Bölgelerinin Sosyo-Kültürel Özellikleri, Ankara, İmar ve İskân Bakanlığı. 